\title{
'Silaturrahim', Malaysian Diaspora and Social Media
}

\author{
AZIAN MUHAMAD ADZMI \\ Cardiff University, Wales \\ NORLIZA SAIFUL BAHRY \\ Universiti Teknologi MARA
}

\begin{abstract}
'Silaturrahim' is a concept of kinship that is unique to the Malays, regardless of where they are in this world. It is a tradition that involves physical actions, and the development in communication has enabled for this to be translated as part of online communication. Using the qualitative approach, through the combination of focus group discussions and in-depth interviews, involving respondents from a wide range of background, this study was carried out to identify the elements of 'silaturrahim' that can be found in social media engagement amongst the diaspora community with a focus on Malaysians who are residing abroad - through the way they communicate with their family members and friends back home, and those who are residing in the same country that they are in, as well as with other Malaysian diaspora communities. The study is focused on the way the Malay diaspora continues the tradition of 'silaturrahim' while forming a positive online culture. The research begins with the diaspora providing their insights on the primary purpose of using social media. As a preliminary finding, in general, most of the interviewees agreed that social media is a means to bring the diaspora community together, particularly if there are events taking place near them, especially when their traditional food is served in the events. The social media is also seen as the most convenient way of conveying information amongst them, and sharing of news both from home as well as where they are residing.
\end{abstract}

Keywords: 'Silaturrahim', Malaysian diaspora, Malay community, culture, social media.

\section{INTRODUCTION}

In a world, full of new information in which various advanced communication technologies are present, people tend to communicate with each other by using the best communication medium with the use of new technology to ensure that the information is easily communicated to the people. Previously, people communicate through telephone and snail mail, where both communication channels sometimes have a lot of distraction and failed to meet their target audience, and for this reason, this would be a part of the communication barrier to having smooth communication channel. With the demand of the era of globalisation, everyone can have their communication tools to make sure that they can be connected to each other without any hesitation and boundaries, and there is no such cost constraint present, and the people will utilise the communication means regardless how costly the system is, as defined in the research of Katz (2017).

Since the advancement of new communication technology had evolved in people's daily life, and people use various communication means to connect themselves with people all around the world (Parkvall et al., 2017). However, the Internet in the past few decades has earned remarkable popularity, specifically for the people who are associated with the field of information searching, and for educational purposes. Furthermore, the people seeking different jobs also use internet. Furthermore, organisations use internet technology to 
market their product. Moreover, people also use the Internet to communicate with people who live abroad, and to keep connected with the people who live far from their country. This had benefited to the not only individual yet to the community as well. The changing information becoming wide with the uses of blogs, messengers, websites, chat rooms, and any others created easy access to gather all information and people tend to use it over and over again. With the use of the Internet, people can communicate easily, and specifically, the smart phones are the one, which keeps the people connected with new and innovative features that support internet technology.

This is what we call social media networking where people socialise themselves online and connected them at any time they want (Anderson \& Jiang, 2018). Overall, social media approaches are used to attract participation among the audience, especially the Diasporas community in information searching and human communication without any hesitation and boundaries.

\section{LITERATURE REVIEW}

There are many studies regarding social media and online participation in society. The involvement does not only include youngsters, but it does also reflect the adult's society (Miller et al., 2016). The researcher's main concentration is the variables that have contributed to the participation of the Social network media among Malaysian diaspora in the United Kingdom. Studies on the participation of social media mainly concentrated on how the Malaysian diaspora getting involved with the activities virtually, gathering online information, and have the social interaction without face-to-face communication can be effective enough in their daily life (Coullie, 2017).

According to Hampton (2016), more youngsters are connecting online than ever before through online gaming, social networking sites, blogs, YouTube, Twitter, WhatsApp, Instagram and a variety of other social networking sites. Akpakwu, Silva, Hancke, and AbuMahfouz (2017), support in his research that social media is already engaging and empowering all youngsters online, and they will think that it was useful enough when connecting them through online were strengthen ties. Besides, Rains and Brunner (2018) coin that if a user wants to reach out to their community and forge relationships that foster cooperation, collaboration, understanding, and lifelong learning and improving well-being between the generations, the way to do it is through the social media. This study will help to determine and explain to society especially Malaysian Diasporas about the significance of social media and their participation in social media is extremely wide in a range that would embrace their way of communication and culture as well (Low, 2017).

Furthermore, this would also take into consideration that active social media participation provides viable means to improve and maintain the Malaysian 'silaturrahim' culture, and to keep them connected with the people of their native country.

This research will evaluate the construction ideas associated with it. First, the contribution of social media among users, they are looking for some information that can contribute not only to their daily use but also to society as a whole (Bucher \& Helmond, 2017). Secondly, social media platform helps to maintain ties among family, relatives, friends, and acquaintances from home country and this research will define, how significantly Malaysian Diasporas are utilising social media platform to promote their 'silaturrahim' culture to host country. 


\section{a. Choice of Social Media}

Today's social media, especially in this new millennium, has changed the lives of everyone in communication. This defines that the social media is the fastest information and empowers in just a second through your fingertips. With social media, every information is there and thereby enhancing knowledge among users. It can be argued that social media is one of the significant revolutions in the digital era, where users try to click or search information by using search engines, and it will appear in seconds, which keeps them engage with society. Based on Dolan, Conduit, Fahy, and Goodman (2016), defining the use of social media networking sites to illustrate this phenomenon, and the term social network page also appears in common discourse, which defines the same aspects, which can be used by individuals to keep them connected with people living abroad. They have suggested that a unique social networking site is not that they allow individuals to meet strangers, but instead, they allow users to articulate and make their social networks look to be easily searched by their acquaintances.

According to Fuchs (2017), the diversity of social media platforms nowadays actually opens up space for users to use them creatively, for example, blogs and Vlogs, where these two platforms can open space for users to apply their ideas creatively, sharing both information and graphics to their readers as well. Choosing social media as the main platform for communicating is also very effective, especially for those who live abroad. This has supported by Hjorth and Hinton (2019), this platform helps to further strengthen the relationship between one another. Time zone differences are no longer becoming boundaries in communication; this allows every relationship to survive even culture can also be embraced wherever the individual is.

As per the research of Blommaert (2016), social media is a tool and platform for people to share opinions, experiences and each other. Borkert (2018) pointed out that social media refers to social applications used to make people connect with each other. Social media applications are based on social functions, which include social networking sites, instant messaging tools, and other Internet vertical applications, which provide aid to the people to keep them connect with the world. Carty (2018) noted in his research that the main social media is widely used by people who live other than their native country. Through the establishment of communication modes with respect to different social media platforms, which are used to improve the quality of communication between people, and it plays a significant role in promoting a good relationship between people who live in different countries. The use of social media tries to smooth the communication mode between people and helps people to better use social media to communicate with each other. Constant (2016) believes that social media is very attractive in people who live in a foreign country because of its convenience, quick news, low cost and much more. The people who live in foreign are becoming more and more important in social media with their sensitivity to new things, and they can earn the information regarding all the circumstances going through in their native country. Dolan et al. (2016) in his research defines that with the advent of smartphones and applications, people use social media anytime and anywhere, which plays a significant role in improving the convenience to communicate with each other. In the present era, mobile phones have long been a must-have item for all the people who live in a civilized society.

Social media has penetrated into every aspect of civilized people's lives, and the impact cannot be misjudged. However, Gomes (2016) in his research defines that a large number of foreign people use social media. Hampton (2016) studied the relationship between 
interpersonal communication and social media platforms, and it has been analysed that foreign individuals often use social media platforms to keep themselves connected with their native people. Koh (2017) defines the short-term use of foreign people, which indicates that social media platform has a greater impact on the lives of foreigners in terms to keep them engaged with their families, and other relatives. This defines that social media is considered as one of the significant platforms for people to keep themselves in touch with their native individuals. Furthermore, Lee (2017) elaborates in his research that foreigners keep themselves engage with both strong and weak ties. The people earn a remarkable amount of information with the use of social media, and the information can keep themselves connected from the people of their native areas, which keep them informed regarding their family members.

\section{b. Social Media and Diaspora Community}

Diaspora comes to be considered as any national social occasion of people scatted from their nation to better places all over the world, national parts of masses dispersed outside the customary nation (Constant \& Zimmermann, 2016). Diaspora's talk, political, specialist, journalistic emphasises an extensive proportion of parts of the miracle: social, culture, language, monetary, politic, communicational, and recorded and happens any place the wonder of people dispersing appears: "Where used to be scatterings, there now is diaspora". "Diasporas are migrants who keep up an association, mental or material, to their place as like home country". Furthermore, Birkenhoff (2011) in his research highlights four different criteria's for their continuation: (i) embracing their culture from the home country; (ii) remain as their eternal place of birth, wanting to return one day; (iii) are devoted to re-establish the country (home country); and (iv) feel with the country that shapes their identity.

Sobré-Denton (2016) defines that, the technology development provides viable means to Diasporas to get in touch with their home country and to have the influence of their native culture in their daily life. Social media is the best platform to foster a love for the country of origin and is capable of maintaining a family relationship despite being in different countries (Kok \& Rogers, 2017). Some deliberation of Diasporas and social media has focused on the transnational estimation of systems administration among dissipated social affairs. Social media ability to diminish the constraints of division interfaces dispersed gatherings which may somehow have little contact (Al-Rawi, 2017). Social media change the progression of Diasporas by empowering new sorts of the relationship among here and home country (Moss, 2018).

\section{c. 'Silaturrahim' and Malaysian Diaspora}

Migrants' ties with their relatives deserted have been progressively explored in the light of the 'monetary, enthusiastic, moral support' mind that substantiates and recreates them (Moss, 2018). Their transnational trade of care assets is extensively comprehended as a twoway, arranged and certainly awry process - one has installed in family administrations of solidarity and commonality, themselves open to change after some time (Borkert, Fisher \& Yafi, 2018). However, the results for those left in the homeland have been talked about in much more profundity than the opposite side of the coin: the processes in which migrants' beneficial experience is influenced by what non-migrant family dictates and expect, yet besides (conceivably) give and assurance. Moderately forsaken are the association between migrants' home-bound duties and commitments, and their particular life conditions, chances, and necessities (Blommaert, 2016). 
Malaysian living abroad still embraced 'silaturrahim' as part of their well-being. They have a good connection among other Malaysian communities surrounding them to feel they as home (Koh, 2017). Malaysian communities living abroad have arranged several other activities as part to strengthen the 'silaturrahim culture, and these activities are one way to promote to their local community, places where they stayed surrounding especially in the United Kingdom (Christou \& Mavroudi, 2016).

Furthermore, the social media culture has been promoted not only by the Malaysian community but government agencies such as Tourism Malaysia. However, Malaysian High Commissioner also played important roles in organising a cultural event for Malaysian and they welcome the locals to participate and celebrate together, for instance, organising open house during Eidul-Fitr (religious celebration), presenting Malaysian traditional cuisine, traditional arts, culture and heritage (i.e Makyong dance, ulit mayang, wayang kulit, and traditional outfits) (Matusky \& Beng, 2017). Lee (2017), defines that Malaysians stay connected with their identity as Malaysian and with these activities they bonded among each other as 'silaturrahim' even though they are from different races and religions, based on Malaysia as a multicultural and multi-racial country.

According to Perry (2017), since the emergence of social media, this special bond as 'silaturrahim' has become easier, and it can even help maintain a distant relationship. With the availability of these social media facilities, government agencies have stepped up their efforts to promote Malaysian arts, culture, and heritage at an international level (Peletz, 2018).

As mentioned by Gomez (2016), even Malaysian communities living abroad have also used this social media as their main platform of contact with each other. All forms of discussion are also easily managed through social media, for example, every Malaysian community has certain community associations, and if they are planning a particular occasion, social media is a platform that helps virtual discussions before the actual roundtable discussion has been made (Wong, 2017).

\section{METHODOLOGY}

This research is conducted after several discussion was made with the focus groups, and this process was adopted to gain the insights from the respondents to the subject under evaluation (Krueger et al., 2014). The reason to carry out these discussions is to determine the association between native Malaysians and Malaysians who are living in the United Kingdom. In this research, two different sessions were held, and in each session, four to five respondents were present and the researcher leads them as a moderator. However, the tenure of each session was of 90 minutes on the venues preferred by respondents. In this research, the respondents were taken from different age groups ranging from 21 to 50 years old. The respondents were professionals, community leaders and students who are a temporary or permanent residents in the United Kingdom. However, in this research, the use of purposive sampling is done, and the focus group is considered as one of the key tools to proceed with qualitative research (Silverman, 2016). The use of qualitative research provides aid to meet the research objectives, pertaining to the understanding regarding the role of social media in the enhancement and development of association among the residents of Malaysia, and those who are residing abroad (Ormston et al., 2014). 
This paper is based on a discussion involving four female respondents and five male respondents. Purposive sampling was utilised to identify respondents through the researcher's networks. At first, only three male respondents were willing to become part of the discussion. However, one of the respondents (respondent A) invited two of his friends to join the discussion group, who's at first, only wanted to be a listener but respondent A managed to convince her friend (respondent $D$ and respondent $E$ ), to participate in the discussion, which increased the number of respondents from three to five.

The location and time have been decided by the respondents which closest to their place, and it is suitable where it is quiet and cosy. The other four female respondents weren't easy as well, particularly to decide the location for discussion to gather them at the same time and place. Finally, one of the respondents (respondent B) offered her place that is convenient for all the other respondents to join the discussion. For location decided by both groups has allowed the researcher (as an interviewer) and moderator to discuss without any hesitation. All nine respondents were unknown to the researcher.

Female respondents were grouped as four in which Respondent $A$ was 21 years old and was an undergraduate student from Leeds University, while Respondent B was a 30-yearold business school postgraduate student from the Sheffield; Respondent $C$ was a 28-year-old pharmacist from Birmingham, and Respondent $D$ was 35 years old an architect residing in Manchester. The average age of the participants was 28.5 years. On the other hand, male respondents were grouped as five in which Respondent A was 36 years old a pharmacist from Southampton; Respondent B was 35 years old an optometrist from Kent; Respondent $C$ was 33 years old an optometrist from Edinburgh, Scotland; Respondent D was 40 years old an entrepreneur from Newcastle, and Respondent $E$ was 40 years old an entrepreneur from Durham and the average age of this group was 36.8 years. The summary of their demographic data is provided in Table 1.

Table 1: Demographic data focus group informants (Female)

\begin{tabular}{|c|c|c|c|c|}
\hline \multicolumn{5}{|c|}{ Female discussion group } \\
\hline Respondent & Age & $\begin{array}{c}\text { Place of residence in the } \\
\text { UK }\end{array}$ & $\begin{array}{l}\text { Ethnic group and state } \\
\text { of origin in Malaysia }\end{array}$ & Social Media Platform \\
\hline \multirow{3}{*}{ A } & \multirow{3}{*}{21} & \multirow{3}{*}{ Leeds } & \multirow{3}{*}{ Bumiputra (Sarawak) } & Facebook \\
\hline & & & & WhatsApp \\
\hline & & & & Instagram \\
\hline \multirow{4}{*}{ B } & \multirow{4}{*}{30} & \multirow{4}{*}{ Sheffield } & \multirow{4}{*}{ Malay (Kelantan) } & Facebook \\
\hline & & & & WhatsApp \\
\hline & & & & Instagram \\
\hline & & & & Twitter \\
\hline \multirow{4}{*}{$\mathrm{C}$} & \multirow{4}{*}{28} & \multirow{4}{*}{ Birmingham } & \multirow{4}{*}{ Malay (Kedah) } & Facebook \\
\hline & & & & WhatsApp \\
\hline & & & & Instagram \\
\hline & & & & Twitter \\
\hline \multirow{4}{*}{$\mathrm{D}$} & \multirow{4}{*}{35} & \multirow{4}{*}{ Manchester } & \multirow{4}{*}{ Malay (Johore) } & WhatsApp \\
\hline & & & & Blogs \\
\hline & & & & Instagram \\
\hline & & & & Twitter \\
\hline
\end{tabular}

*PSN = PlayStation Networking 
Table 2: Demographic data focus group informants (Male)

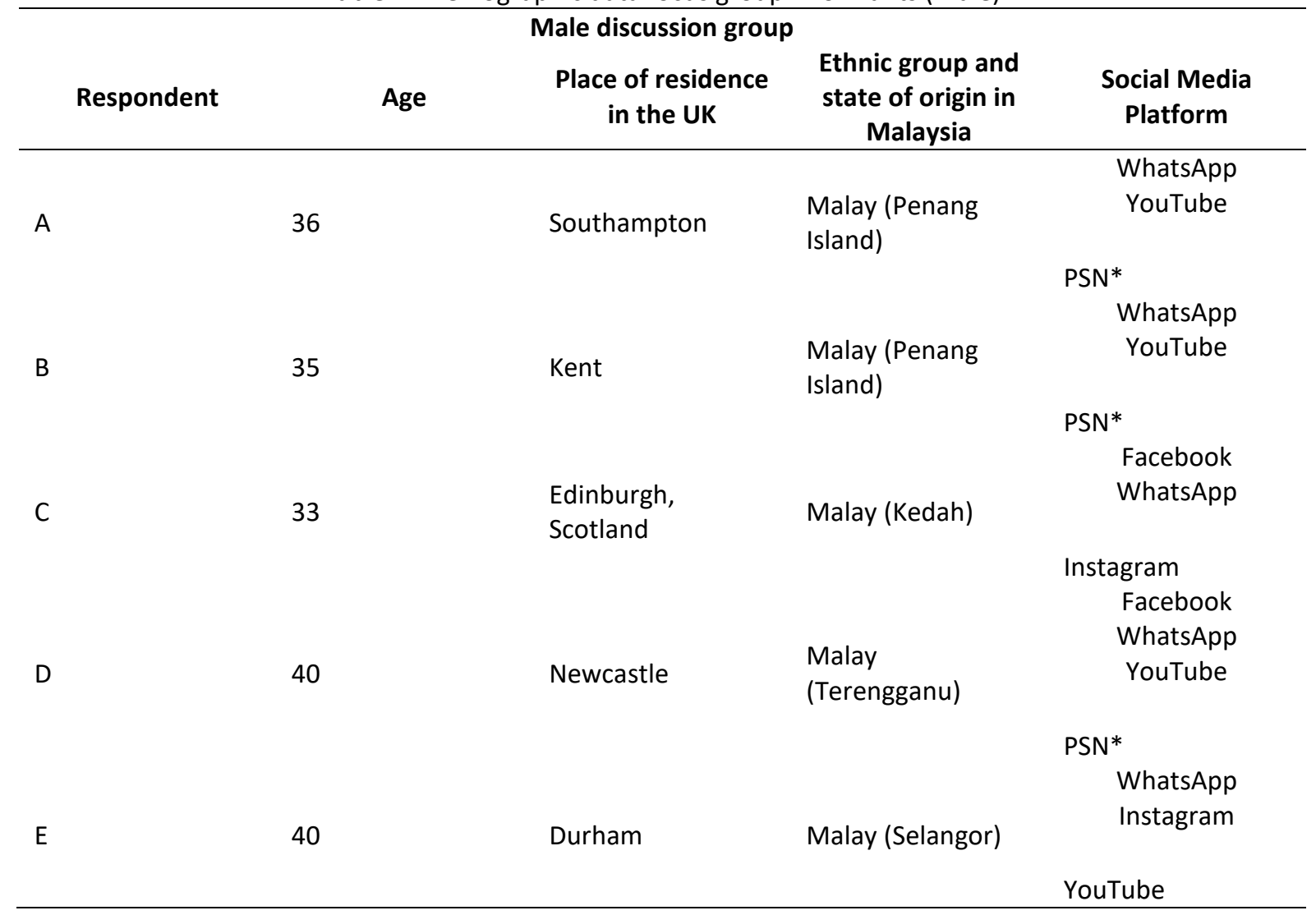

*PSN = PlayStation Networking

\section{Procedure}

In this research, careful means were integrated to proceed with the planning process. The discussion was conducted as per the reference of the respondents. The reason to take interviews on their preferred location is to make respondents feel comfortable and the discussion can be done appropriately. According to Jafari and Scott (2014), the interviews should be taken on respondent preferred places, and it provides an aid for the researcher to gain the required information associated with their personal experience, and their preferred places will make them comfortable to proceed with the required discussion. Before starting the discussion, the researcher explained the purpose of the research.

Moreover, the written consent was taken from all the respondents, and the researcher started to ask the required questions. Furthermore, the flow of discussion was solely based on the respondent's behaviour on how they answer and how they are associated with social media while living abroad. The way respondents communicate increased the 'silaturrahim'. Moreover, the researcher ensures to maintain her role as a facilitator, and the researcher also ensures that no element should be included in this whole process, which can lead the respondents to feel biased. However, the tenure of 72 minutes was there, and the responses were also recorded to facilitate the discussion transcripts, and the data can be analysed after the whole process is finalised. The details provided in the discussion are only present in this researcher, and the respondent's name was not disclosed, and all the data after the analysis was destroyed. Moreover, the questions were categorised into three different sections, which are listed below: 
i. Attitudes towards the choice of social media.

ii. Attitudes towards the diaspora community.

iii. Attitudes towards 'silaturrahim' concepts

Table 3: The semi-structured questions that guide the group discussion

\begin{tabular}{cl}
\hline Number & Questions \\
\hline 1 & How many social media accounts do you have and what are they? What is the main purpose \\
of using these accounts? \\
How do this community been developed? Why do Malaysian decide to stay abroad? Do \\
you think economic development increasing impact for Malaysian migrate to other \\
countries? Why? How do you foresee this community in the future? \\
In this community, who makes the decisions about the "silaturrahim" activities? (Probe: \\
Religious or community leaders? Others?) \\
- Who makes decisions about the venue, time, financial? \\
- How are these decisions made? \\
$\quad$ What type of medium of communication being used? (Probe: Social \\
What is your understanding of the term 'silaturrahim' or bond? What are your views \\
regarding 'silaturrahim' online (could you elaborate that please? Do you think that \\
'silaturrahim' began with the emergence of social media?) (Has your bond with family \\
members and friends improved because of social media, why/why not?) (Do you think that \\
physical interaction is more important in maintaining 'silaturrahim'?) \\
How can Malaysians maintain the 'silaturrahim' culture by leveraging social media?
\end{tabular}

\section{RESULTS AND DISCUSSION}

This research is based on thematic analysis, and the data was used to extract the information taken from the focus groups, which provides aid to develop multiple themes. The analysts define that the use of thematic analysis provides significant means to evaluate different viewpoints defined by different researchers. This is considered as one of the key reasons to incorporate the hypothetical view, which is considered as one of the adaptable methodologies, and the idle parts can be incorporated in the research (Braun et al., 2019). However, at this point, the respondent's viewpoints are recorded based on their experience. The themes were developed based on collected data, and table 3 indicates that responses of nine respondents and the themes were developed based on these responses. However, three main themes were developed, and the sub-themes were developed based on three main themes.

In this research, numerous themes were developed with the use of thematic analysis, and the original extracts obtained from the responses are defined to ensure discussion transparency. Furthermore, the themes were categorised into two different categories, and each theme emerged from the research objectives.

Table 4: List of themes and subthemes

\begin{tabular}{lll}
\hline \multicolumn{1}{c}{ Theme } & \multicolumn{1}{c}{ Subtheme } \\
\hline Social Media Platform & $\bullet$ Preferred platform \\
Diaspora community & $\bullet$ Purpose of use \\
'Silaturrahim' concepts & $\bullet$ Migration purposes \\
& $\bullet$ activities \\
\hline
\end{tabular}




\section{Preferred Platform}

\section{ATTITUDE TOWARDS CHOICE OF SOCIAL MEDIA}

The study identified social media as the preferred platform among both groups are WhatsApp where it is simple, fast and more personal direct to the receiver. However, their second preferred are different among female group and male group. It is shown that three respondents $(A, B$, and $C)$ use Facebook to update status, upload photos and read comments. On the contrary, three respondents (A, B, and D) from the male group prefer to use PSN as their second choice of social media platform:

Table 5(i): P platform (Female discussion group)

\begin{tabular}{|c|c|}
\hline Subtheme & $\begin{array}{l}\text { Female Respondents } \\
\end{array}$ \\
\hline \multirow{9}{*}{ Preferred platform } & "I prefer to use Facebook because I can update my status together with photos," \\
\hline & Respondent D \\
\hline & "I agree with respondent $D$, I am also preferred to Facebook not just to update my \\
\hline & status but I read some of my friends' status too and WhatsApp is for my personal \\
\hline & message between my favourite person to communicate," \\
\hline & Respondent B \\
\hline & "I use Facebook to update status, read some comments and replied to it but I like \\
\hline & WhatsApp more," Respondent A \\
\hline & $\begin{array}{l}\text { "It is everyone favourite actually and I'm one of them too, I use both WhatsApp and } \\
\text { Facebook" Respondent C }\end{array}$ \\
\hline & Table 5(ii): Preferred platform (Male discussion group) \\
\hline Subtheme & Male Respondents \\
\hline \multirow{9}{*}{ Preferred platform } & $\begin{array}{l}\text { "The most frequent social media that I've got connected is WhatsApp. However, I } \\
\text { love to play games so my second choice is PSN, while I play the game, I can } \\
\text { communicate with my siblings," Respondent D }\end{array}$ \\
\hline & "Same with me, I played PSN to get connected with my siblings and friends in \\
\hline & Malaysia, but WhatsApp is more personal," Respondent A \\
\hline & "I like to use WhatsApp, the other platform just to equip my time," Respondent C \\
\hline & \\
\hline & $\begin{array}{l}\text { "I have my own YouTube channel for me to upload any video whenever I go for a } \\
\text { travel but WhatsApp is for my personal use," Respondent E }\end{array}$ \\
\hline & $\begin{array}{l}\text { "My WhatsApp to communicate through text with my groups that I in and for my } \\
\text { close family and friends, I like to do video call to share my good and bad time. }\end{array}$ \\
\hline & However, I use PSN to spend my time with my siblings and friends who are gamers \\
\hline & where we can chat and entertain each other while in the character in the games," \\
\hline
\end{tabular}

\section{Purpose of Use}

The study found that the majority of respondents used social media as a platform for them to interact with their families in Malaysia and to find interesting news on political and economic developments and sometimes just to read about entertainment news related to their favourite celebrities. Only one respondent used social media as a place for her to look for job opportunities upon graduation: 
Table 6(i): Purpose of use (Female discussion group)

\begin{tabular}{|c|c|}
\hline Subtheme & Female Respondents \\
\hline \multirow{5}{*}{ Purpose of use } & $\begin{array}{l}\text { "I am too clingy so I really need to know about my parents and my siblings too, I } \\
\text { really miss them," Respondent D }\end{array}$ \\
\hline & $\begin{array}{l}\text { "Family is my everything besides that I like to read news about my favourite } \\
\text { celebrities," Respondent B }\end{array}$ \\
\hline & \\
\hline & $\begin{array}{l}\text { "Since we have changed the government, I just need to know what's new, it does } \\
\text { concern me because I am Malaysian after all," Respondent C }\end{array}$ \\
\hline & $\begin{array}{l}\text { "I always check any jobs opportunity from any social media account that I own and } \\
\text { sometimes I asked my friends to inform me about this," Respondent A }\end{array}$ \\
\hline \multicolumn{2}{|r|}{ Table 6(ii): Purpose of use (Male discussion group) } \\
\hline Subtheme & Male Respondents \\
\hline \multirow{5}{*}{ Purpose of use } & $\begin{array}{l}\text { "All my family member now get use to communicate through WhatsApp so we like to } \\
\text { share every news in our family group in WhatsApp," Respondent B }\end{array}$ \\
\hline & $\begin{array}{l}\text { "I use to call my family to ask about how are they doing and share everything about } \\
\text { my condition living far apart from them," Respondent E }\end{array}$ \\
\hline & $\begin{array}{l}\text { "I have my own YouTube channel so I asked all my family members to subscribe my } \\
\text { channel and from this channel they will know my activities while I gone for travel," } \\
\text { Respondent A }\end{array}$ \\
\hline & $\begin{array}{l}\text { "I use my Facebook and WhatsApp to read news about my country and to } \\
\text { communicate with my family and," Respondent D }\end{array}$ \\
\hline & $\begin{array}{l}\text { "WhatsApp is the easiest way to have direct contact with my family and friends, but } \\
\text { Facebook, I can read news from the newsfeed and I can search my other fellow } \\
\text { friends," Respondent C. }\end{array}$ \\
\hline
\end{tabular}

\section{ATTITUDES TOWARDS DIASPORA COMMUNITY}

\section{Migration Purposes}

This study identifies several reasons for the movement that have taken place among Malaysians becoming part of the diaspora community, especially living in the United Kingdom. By the collective analysis of the responses given from all respondents it was observed that most respondents agree that educational opportunity is the main reason they decided to move abroad, furthermore beside education benefit, respondent $B$ has mentioned on the medical advancement and some of them because of they have the job opportunity after graduation and according to respondent $D$ and $E$ from the male group, they have the opportunity to expand their business:

Table 7(i): Migration purposes (Female discussion group)

\begin{tabular}{ll}
\hline Subtheme & Female Respondents \\
\hline & $\begin{array}{l}\text { "I received scholarship from MARA and have the opportunity to further my study } \\
\text { Migration purposes }\end{array}$ \\
& $\begin{array}{l}\text { "I agree with respondent A. I have to opportunity to further my PhD abroad in one } \\
\text { of top University in UK while receiving a scholarship from KPT," Respondent B }\end{array}$
\end{tabular}


"Before graduate, I've been doing my internship with one of organization here, and they have offered a job once I graduate," Respondent C

"I am an architecture graduate, at first, I went back to Malaysia to look for a job but after sometimes becoming as jobless then I decided to try my luck look any job opportunity in UK, later I had my chance to work here," Respondent D

Table 7(ii): Migration purposes (Male discussion group)

\begin{tabular}{l} 
Subtheme Male Respondents \\
\hline "I've been offering a job that I have applied since I in Malaysia, I takt the chance to \\
accept the offer, " Respondent C \\
"My wife is a medic student and I run a small business, when I have the opportunity \\
to expand my business here then we decided just to take the opportunity and stay \\
here," Respondent E \\
"I have my business partner here, I keep back and forth like few years and after a \\
while, I decided to move here and run my business with my partner permanently," \\
Respondent D \\
"I decided to stay here for my children education benefits and I have a child that \\
treated as ADHD where here I can have better medical treatment for him," \\
Respondent B \\
"I studied in Cardiff University before and before I graduate I need to complete with \\
my practice in one of pharmaceutical organization here, after a while like a year \\
later, I've been offered a job then I decided to grab the job," Respondent A
\end{tabular}

\section{ATTITUDE TOWARDS 'SILATURRAHIM' CONCEPTS}

\section{Activities}

This study found that Malaysian understanding of the concept of 'silaturrahim' was shaped by activities that enabled them to enhance their 'silaturrahim' even they lived abroad. Respondents A, B, and D of the female group found that activities such as cooking or brewing were their primary choice of 'silaturrahim', but only respondent $C$ from the same group felt that exchanging dishes during the fasting month could bring 'silaturrahim'. While the majority of the respondents were from the male group, they preferred to do activities such as ngeteh for 'silaturrahim' among them:

Table 8(i): Activities (Female discussion group)

Subtheme $\quad$ Fe change dishes during fasting month is one of the simple activities that we can
do to shape our 'silaturrahim," Respondent C
"We have organized community gathering each year, thus we did some rewang
before the event where we can cook together," Respondent B
"Yeah...yeah...that's true, in my place too we do small gathering among Malaysian
community and we did the rewang too," Respondent D
"That's true, rewang is the best activity we did especially when we celebrate Eid,"
Respondent A


Table 8(ii): Activities (Male discussion group)

\begin{tabular}{l} 
Male Respondents \\
\hline "Me and many other Malaysian community like to have a cup of coffee like ngeteh \\
where we share many fun stories while drinking our coffee," Respondent C \\
"We do our ngeteh session especially among men members in nearest coffee shop, \\
it is fun actually to have friends that share stories," Respondent E \\
"Me and my friends like to talk about politic especially Malaysia political situation, \\
so we go grab coffee together and talk about it or maybe in Malaysia we call it as \\
ngeteh," Respondent D \\
"That's similar to us here in Kent, even though Malaysian here are just small \\
population but we did our ngeteh session talk about political situation in Malaysia," \\
Respondent B \\
"I always call my friends to come over to my place to have some coffee and goreng \\
pisang (fried banana) for like tea time but we as Malaysian call it ngeteh, right...so \\
yeah they come over to my place to have our ngeteh time," Respondent A
\end{tabular}

\section{Online group}

Based on the collective analysis of responses received from all respondents, it was found that most respondents had an online group to maintain their 'silaturrahim'. These online groups comprise several groups such as family groups, friends' groups, neighbourhood group and officemate groups that still in Malaysia. The female respondents were most active in interacting with Malaysian community WhatsApp groups in their residence in the United Kingdom, compared to their male respondents who were passive interact but more to read and observed in community groups, but they actively interact with an individual through WhatsApp:

Table 9(i): Online group (Female discussion group)

\begin{tabular}{|c|c|}
\hline Subtheme & Female Respondents \\
\hline \multirow{4}{*}{ Online group } & $\begin{array}{l}\text { "I have several online groups in my WhatsApp such as my family, friends and } \\
\text { colleague in Malaysia," Respondent A }\end{array}$ \\
\hline & $\begin{array}{l}\text { "I use WhatsApp, Facebook and we have our group from both platform for family } \\
\text { and friends in Malaysia," Respondent }\end{array}$ \\
\hline & $\begin{array}{l}\text { "My friends from previous university in Malaysia have created a Facebook page } \\
\text { only for our batch so we use to share our story through Facebook but for my family } \\
\text { I am one of member in my family group in WhatsApp," Respondent D }\end{array}$ \\
\hline & $\begin{array}{l}\text { "I only use WhatsApp. So, I active to communicate with all the group that I in, } \\
\text { including Malaysian community here in Sheffield," Respondent B }\end{array}$ \\
\hline \multicolumn{2}{|r|}{ Table 9(ii): Online group (Male discussion group) } \\
\hline Subtheme & Male Respondents \\
\hline \multirow[b]{2}{*}{ Online group } & $\begin{array}{l}\text { "I have many groups in my WhatsApp but not all that I really active with, } \\
\text { sometimes just scroll everything, respond whenever it is important," Respondent C }\end{array}$ \\
\hline & $\begin{array}{l}\text { "I am a gamer so I active to use PSN and have my own gamers group in PSN, unlike } \\
\text { Facebook, it is more to the other public and for WhatsApp I have a family group } \\
\text { and my ex-colleague group in Malaysia," Respondent D }\end{array}$ \\
\hline
\end{tabular}




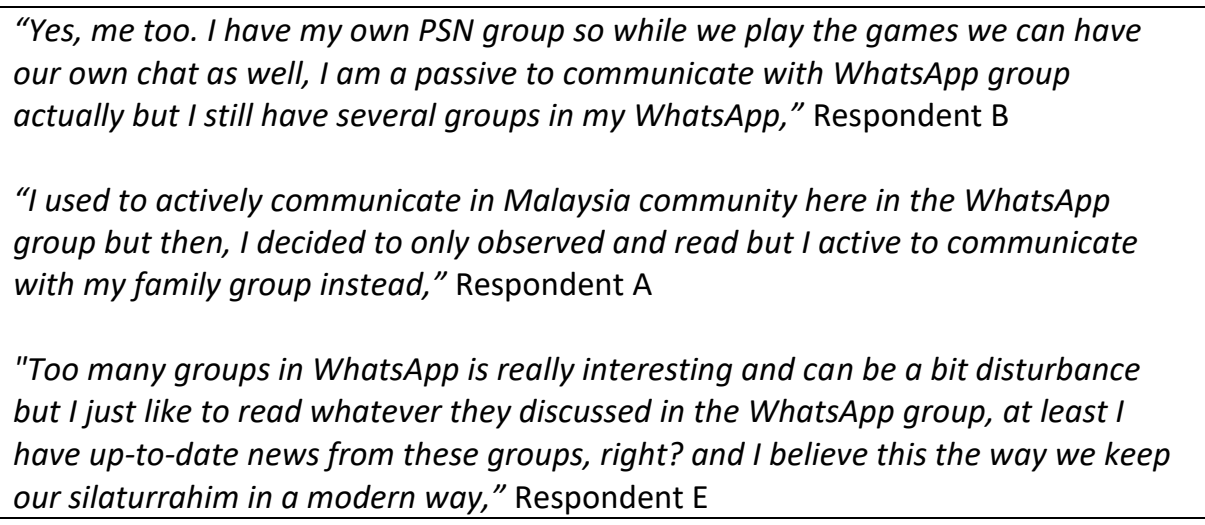

\section{CONCLUSION}

Based on the findings of discussion, it is found that the concept of 'silaturrahim' among Malaysian communities living abroad is still practised as much as it is in Malaysia. Activities such as rowing, exchanging dishes and so on are still practised to foster 'silaturrahim' even though they are not of the same bloodline but they do feel like a family. This study found that some of the Malaysian community that migrated and became a diaspora community was not only looking for better education and employment opportunities but also to provide valuable experience for them in addition to expanding their business and gaining medical sophistication in the United Kingdom. Other insights, such as using social media as a platform for them to stay in touch with family and friends in Malaysia have also been identified as part of their 'silaturrahim' related activities. There were some limitations during this study, including time and place constraint as most of the respondents consisted of employment groups and their time was difficult to determine for them to sit in groups at the stated time. Besides, these two groups remain female and male; thus, researchers suggest for future studies to identify a group that has a mix of genders to allow for a broader perspective. Furthermore, the reason that the results of other focus groups are not included because the responses earned from the included focus groups were close to the research topic, and it provides an aid to gain a detailed insight to answer the research questions, and to achieve research aim appropriately.

BIODATA

Azian Muhamad Adzmi is a final year PhD researcher in School of Journalism, Media \& Cultural Studies (JOMEC) at Cardiff University, Wales, United Kingdom. Email: MuhamadAdzmiA@cardiff.ac.uk

Norliza Saiful Bahry is a senior lecturer in Faculty of Business Management at Universiti Teknologi MARA, Malaysia. Email: norliz2956@uitm.edu.my 


\section{REFERENCES}

Akpakwu, G. A., Silva, B. J., Hancke, G. P., \& Abu-Mahfouz, A. M. (2017). A survey on 5 G networks for the Internet of Things: Communication technologies and challenges. IEEE Access, 6, 3619-3647.

Al-Rawi, A. (2017). Facebook and virtual nationhood: Social media and the Arab Canadians community. Al \& Society, 1-13.

Anderson, M., \& Jiang, J. (2018). Teens, social media \& technology 2018. Pew Research Center, 31, 2018.

Brinkerhoff, J. M. (2011). Diasporas and conflict societies: Conflict entrepreneurs, competing interests or contributors to stability and development? Conflict, Security \& Development, 11(02), 115-143.

Blommaert, J. (2016). New forms of diaspora, new forms of integration. Tilburg Papers in Culture Studies. Retrieved from https://www.tilburguniversity.edu/upload/ba515695257b-4dd0 b030-b52a158c7a42_TPCS_160_Blommaert. pdf

Borkert, M., Fisher, K. E., \& Yafi, E. (2018). The best, the worst, and the hardest to find: How people, mobiles, and social media connect migrants in (to) Europe. Social Media+ Society, 4(1). Doi: 10.1177/2056305118764428

Braun, V., Clarke, V., Hayfield, N., \& Terry, G. (2019). Thematic analysis. Handbook of Research Methods in Health Social Sciences, 843-860.

Bucher, T., \& Helmond, A. (2017). The affordances of social media platforms. The SAGE Handbook of Social Media, 223-253.

Carty, V. (2018). Social movements and new technology. London: Routledge.

Christou, A., \& Mavroudi, E. (2016). Dismantling diasporas: Rethinking the geographies of diasporic identity, connection and development. London: Routledge.

Constant, A. F., \& Zimmermann, K. F. (2016). Diaspora economics: New perspectives. International Journal of Manpower, 37(7), 1110-1135.

Coullie, J. L. (2017). Diasporas, cultures of mobilities, 'race': 1. Diasporas and cultures of migrations. Ariel, 48(2), 179.

Dolan, R., Conduit, J., Fahy, J., \& Goodman, S. (2016). Social media engagement behaviour: A uses and gratifications perspective. Journal of Strategic Marketing, 24(3-4), 261-277.

Fuchs, C. (2017). Social media: A critical introduction. London: Sage.

Gomes, C. (Ed.). (2016). The Asia-Pacific in the age of transnational mobility: The search for community and identity on and through social media (Vol. 1). New York: Anthem Press.

Hall-Phillips, A., Park, J., Chung, T. L., Anaza, N. A., \& Rathod, S. R. (2016). I (heart) social ventures: Identification and social media engagement. Journal of Business Research, 69(2), 484-491.

Hampton, K. N. (2016). Persistent and pervasive community: New communication technologies and the future of the community. American Behavioral Scientist, 60(1), 101-124. doi: 10.1177/0002764215601714

Hjorth, L., \& Hinton, S. (2019). Understanding social media. London: Sage.

Jafari, J., \& Scott, N. (2014). Muslim world and its tourisms. Annals of Tourism Research, 44, 1-19.

Katz, J. E. (2017). Machines that become us: The social context of personal communication technology. London: Routledge.

Koh, S. Y. (2017). Race, education, and citizenship: Mobile Malaysians, British colonial legacies, and a culture of migration. London: Springer. 
Kok, S., \& Rogers, R. (2017). Rethinking migration in the digital age: Transglocalization and the Somali diaspora. Global Networks, 17(1), 23-46. doi: 10.1111/glob.12127

Krueger, R. A., \& Casey, M. A. (2014). Focus groups: A practical guide for applied research. London: Sage.

Lee, R. L. (2017). Malaysian identities and mélange food cultures. Journal of Intercultural Studies,_38(2), 139-154. doi: 10.1080/07256868.2017.1289907

Low, C. C. (2017). Malaysian diaspora philanthropy: Transnational activism, mobilization and resistance. Diaspora Studies, 10(2), 152-174.

Matusky, P., \& Beng, T. S. (2017). The music of Malaysia: The classical, folk and syncretic traditions. London: Routledge.

Miller, D., Costa, E., Haynes, N., McDonald, T., Nicolescu, R., Sinanan, J., Spyer, J., Venkatraman, S., \& Wang, X. (2016). How the world changed social media (Vol. 1). UK: UCL Press.

Moss, D. M. (2018). The ties that bind: Internet communication technologies, networked authoritarianism, and 'voice' in the Syrian diaspora. Globalizations, 15(2), 265-282. doi: $10.1080 / 14747731.2016 .1263079$

Muhammad, R., Zahari, M. S. M., Shariff, M. S. M., \& Abdullah, K. M. (2016). Malaysian foodways: Acculturation/assimilation towards authenticity sustainability among diasporic community. Procedia-Social and Behavioral Sciences, 222, 367-373. doi: 10.1016/j.sbspro.2016.05.184

Ormston, R., Spencer, L., Barnard, M., \& Snape, D. (2014). The foundations of qualitative research. Qualitative Research Practice: A Guide for Social Science Students and Researchers, 2, 52-55.

Parkvall, S., Dahlman, E., Furuskar, A., \& Frenne, M. (2017). NR: The new 5 G radio access technology. IEEE Communications Standards Magazine, 1(4), 24-30. doi: 10.1109/MCOMSTD.2017.1700042

Peletz, M. G. (2018). Islamic modern: Religious courts and cultural politics in Malaysia (Vol.11). Princeton: Princeton University Press.

Perry, M. S. (2017). Feasting on culture and identity: Food functions in a multicultural and transcultural Malaysia. 3L: Language, Linguistics, Literature ${ }^{\circledR}$, 23(4). doi: 10.17576/3L2017-2304-14

Radde-Antweiler, K., \& Zeiler, X. (Eds.). (2018). Mediatized religion in Asia: Studies on digital media and religion. London: Routledge.

Rains, S. A., \& Brunner, S. R. (2018). The outcomes of broadcasting self-disclosure using new communication technologies: Responses to disclosure vary across one's social network. Communication Research, 45(5), 659-687.

Silverman, D. (Ed.). (2016). Qualitative research. London: Sage.

Sobré-Denton, M. (2016). Virtual intercultural bridgework: Social media, virtual cosmopolitanism, and activist community-building. New Media \& Society, 18(8), 17151731. doi: $10.1177 / 1461444814567988$

Wong, J. W. (2017). 'So that she feels a part of my life': How international students connect to home through digital media technologies. In International Student Connectedness and Identity (pp. 115-135). Singapore: Springer. 